\title{
Immune status at pre-treatment impacts on progression-free survival of metastatic colorectal cancer patients treated with first-line chemotherapy
}

\author{
Kohei Tada ${ }^{*}$, Shigehisa Kitano ${ }^{2}$, Hirokazu Shojii, Takashi Nishimura ${ }^{4}$, Yasuhiro Shimada ${ }^{3}, K^{3}$ engo Nagashima ${ }^{5}$, \\ Yoshitaka Honma ${ }^{3}$, Satoru Iwasa ${ }^{3}$, Natsuko Okita ${ }^{3}$, Atsuo Takashima ${ }^{3}$, Ken Kato ${ }^{3}$, Yasuhide Yamada ${ }^{3}$, \\ Naoyuki Katayama ${ }^{6}$, Narikazu Boku ${ }^{3}$, Tetsuya Hamaguchi ${ }^{3}$, Yuji Heike ${ }^{3}$
}

From 30th Annual Meeting and Associated Programs of the Society for Immunotherapy of Cancer (SITC 2015) National Harbor, MD, USA. 4-8 November 2015

\section{Background}

Immunological status in surgically resected specimens affects the outcome of 'operable' colorectal cancer patients. For example, a high number of tumor infiltrating lymphocytes, $\mathrm{CD}^{+}$cells, $\mathrm{CD}^{+}$cells, or $\mathrm{CD}_{4} 5 \mathrm{RO}^{+}$cells in a tumor is associated with improved prognosis. However, it has not been determined whether the immunological status in peripheral blood affects the outcome of 'inoperable' metastatic colorectal cancer (MCRC) patients. We investigated the impact of peripheral immunological status at pre-treatment on progression-free survival (PFS) of MCRC patients.

\section{Methods}

Peripheral blood was prospectively collected from consecutive MCRC patients $(n=40)$ before they received a first-line chemotherapy. The quantity of each of 25 immune subsets, including monocytic myeloid-derived suppressor cells (M-MDSC, defined as Lineage ${ }^{-} \mathrm{CD} 14^{+}$ $\mathrm{CD}_{11 \mathrm{~b}^{+} \mathrm{CD} 33^{+} \text {HLA-DR }}{ }^{\text {low } /-}$ ) and effector memory $\mathrm{T}$ cells $\left(\mathrm{T}_{\mathrm{EM}}\right.$, defined as $\mathrm{CD} 3^{+} \mathrm{CD} 4^{+}$or $\mathrm{CD} 8^{+} \mathrm{CD} 45 \mathrm{RA}^{-}$ $\mathrm{CCR7}^{-}$) was measured using multicolor-flow cytometry. The patients were divided into high (> median) and low ( $<$ median) groups based on the median value for each immune subset. PFS was compared between the two patient groups.

'St. Lukes's International Hosp., Immunotherapy \& Cell Therapy, Tokyo, Japan Full list of author information is available at the end of the article

\section{Results}

Of the 25 immune subsets quantified, we identified a high quantity of M-MDSC, a low quantity of $C D 4^{+} \mathrm{T}_{\mathrm{EM}}$, or a low quantity of $\mathrm{CD}^{+} \mathrm{T}_{\mathrm{EM}}$ as adverse prognostic factors for PFS. Thus, patients with high M-MDSC, low $\mathrm{CD} 4^{+} \mathrm{T}_{\mathrm{EM}}$ or low $\mathrm{CD} 8^{+} \mathrm{T}_{\mathrm{EM}}$ had significantly shorter PFS than those with low M-MDSC, high $C D 4^{+} \mathrm{T}_{\mathrm{EM}}$, or high $\mathrm{CD} 8^{+} \mathrm{T}_{\mathrm{EM}}$, respectively $(\mathrm{p}=0.004,0.005$, and 0.002 , respectively). Ten (25\%) patients had three adverse factors, $11(27.5 \%)$ patients had 2, $8(20 \%)$ patients had one, and $11(27.5 \%)$ patients had none. Patients were classified into two distinct prognostic groups based on the number of adverse factors that were present in each patient. The presence of 2 or 3 adverse factors $(n=21$, $52.5 \%)$ correlated with significantly shorter PFS compared to the presence of no or 1 adverse factor $(n=19$, $47.5 \%)(\mathrm{p}=0.00001)$. In addition, multivariate analysis showed that the presence of 2 or 3 adverse factors was an independent poor prognostic factor for PFS (Hazard ratio, 10.2; 95\% confidence interval, 2.9-35.9; $\mathrm{p}=0.0003$ ) after adjustment for previously known prognostic factors.

\section{Conclusions}

These results suggest that peripheral immune status at pre-treatment impacts on the prognosis of MCRC patients treated with first-line chemotherapy.

\section{Authors' details}

${ }^{1}$ St. Lukes's International Hosp., Immunotherapy \& Cell Therapy, Tokyo, Japan. ${ }^{2}$ Dept. of Exp. Therap., Natl. Cancer Ctr. Hosp., Tokyo, Japan. ${ }^{3}$ National Cancer Center Hospital, Tokyo, Japan. ${ }^{4}$ Tokyo Jikei Medical University, Tokyo, Japan. 
Published: 4 November 2015

doi:10.1186/2051-1426-3-S2-P108

Cite this article as: Tada et al:: Immune status at pre-treatment impacts on progression-free survival of metastatic colorectal cancer patients treated with first-line chemotherapy. Journal for ImmunoTherapy of

Cancer 2015 3(Suppl 2):P108.

Submit your next manuscript to BioMed Central and take full advantage of:

- Convenient online submission

- Thorough peer review

- No space constraints or color figure charges

- Immediate publication on acceptance

- Inclusion in PubMed, CAS, Scopus and Google Scholar

- Research which is freely available for redistribution

Submit your manuscript at www.biomedcentral.com/submit
() Biomed Central 